\title{
TRADISI NIKAH KAWIN MASYARAKAT KECAMATAN RUMBAI KOTA PEKANBARU
}

\author{
Juswandi \\ Universitas Lancang Kuning Pekanbaru \\ juswandi@unilak.ac.id
}

\begin{abstract}
Abstrak
Penelitian ini berjudul "Upacara Aadat Perkawinan Masuarakat Kecamatan Rumbai Pekanbaru Provinsi Riau” Tujuan penelitianiniadalah mengetahui dan tata cara upacara adat perkawinan.penelitian ini berlokasi di Kecamatan Rumbai Provinsi Riau. Penelitian ini menggunakan metode kualitatif dan deskriptif dengan cara pendekatan wawancara dan di rekam kemudian di catat. Setiap suku dan etnik setiap suku dan bangsa memiliki adat dan tradisi yang berbeda-beda, hal ini terlihat ketika adat pernikahan khususnya di Kecamatan Rumbai Pekanbaru mulai dari persiapan pernikahan sampaike pelaminan.
\end{abstract}

Kata kunci : Upacara Perkawinan

\begin{abstract}
Abstrack
The litle of the resarch is traditional marriage for the society in the districk of rumbai-pekanbaru. The aims of the resarch are to investigate, analyze And documenting the procedures of traditional marriage ceremony this area.the research is located in the districk of rumbai-pekanbaru. In analyzing this research, the writer applies a descriptive qualtative method in wich the result of the analyzis will be descrobed clearly. The data was taken by using interview, records and notes, the result shown that every tribe and ethnic has different customs and traditions. This can be seen at the time of the marriage process especially in the districk of rumbai-pekanbaru starting from marriage preparation until wedding ceremony.
\end{abstract}

Keywords: traditional marriage cermony, customs and traditions 


\section{Pendahuluan}

Ini adalah kajian Tradisi Ijab Kobul Nikah Kawin Masyarakat Kecamatan Rumbai Kota Pekanbaru Provinsi Riau. Secara umum, adat perkawinan atau nikah kawin ini di mulai dari tradisi merisik dan diakhiri dengan duduk bersanding di pelaminan. Dari keseluruhan akan terlihat jelas kebudayaan Melayu yang dimiliki oleh masyarakat Melayu Kecamatan Rumbai Provinsi Riau dan banyak ragamnya. Tradisi upacara perkawinan ini mengandung banyak keanekaragaman yang harus di tempuh langkah-langkahnya sesuai dengan status sosialnya, Untuk golongan raja, bangsawan, perbedaannya dengan orang biasa, di lihat dari warna baju yang di pakai oleh pengantin dan bentuk pelaminan, yang bertingkat-tingkat.

Adat tradisi nikah kawin merupakan suatu keperluan laluriah yang mesti di adaadakan. Pada dasarnya perkawinan adalah membentuk keluarga yang akan membuahkan zuriat atau keturunan yang menyambung kehidupannya, cita-citanya dan mendoakannya. Karena perkawinan demikian pentingnya dalam kehidupan manusia maka padanya berlaku bermacam-macam aturan yang kemudian menjadi adat tradisi.

Adapun perkawinan menurut masyarakat mempunyai beberapa tujuan. Tujuan yang paling penting dan utama adalah untuk memenuhi adat itu sendiri. Oleh karena itu, perkawinan telah di anggap sebagai adat yang harus di tempuh oleh setiap manusia, maka perkawinan itu sendiri merupakan keharusan yang akan dirasakan, janggal apabila seseorang menikah dan tidakmengikuti sunnah nabi Muhammad saw.

Untuk melaksanakan perkawinan tidak boleh berkata tidak ada, sebab apa yang tidak ada harus diadakan kalau sudah tiba saatnya menikah. Tidak dapat yang sangat baik yang sedang saja jadilah. Pendek kata hal tersebut harus dilaksanakan berdasarkan adatnya masing-masing. Untuk menghadapi upacara perkawinan tidak heran jika seseorang itu sampai-sampai menggadaikan hartanya, demi terlaksanaupacra adat nikah kawin dengan tatacara adatnya, suatu perbuatan yang dianggap sudah lazim dilakukan.

Oleh karena adat perkawinan bukanlah masalah perseorangan melainkan menyangkut orang banyak, maka segala sesuatu yang bersangkutan dengan adat perkawinan tersebut sudah menjadi tanggung jawab bersama. Apabila dalam suatu keluarga terdapat seorang gadis yang telah cukup umur, apa lagi umurnya sudah melebihi dari kepatutan, dan belum mempunyai suami, atau seorang bujang yang tidak beristri, maka seluruh anggota keluarga akan merasa aib (malu) ketika waktunya sudah berumah tangga 
Mereka akan menanggung malu yang tak terkira, oleh karena itu setelah seseorang anggota keluarga memulai tanggung jawabnya untuk mencarikan jodoh atau menantu, maka segala persiapan harus dilakukan persiapannya untuk menyongsong hari perkawinan anaknya. Makin besar anak maka semakin dekat masa penantian untuk menikah sebagai tanggung jawab dari pada keluarganya.

Keluarga yang mempunyai anak perempuan mulailah menyiapkan rumah dan perabotnya, bagi yang memiliki anak laki-laki mengarahkan anaknya untuk mencari kehidupan agar kelak dapat menghidupi keluarganya secara mandiri dan jangan lagi mengharap banyak bantuan dari pada orang tua. Semua itu telah menjadi adat istiadat yang harus dipenuhi.

Orang Melayu identitasnya dengan tiga ciri khas pokok, yaitu berbahasa Melayu, beradat-istiadat Melayu dan beragama Islam. (Tenas Effendy, Dalam Tunjuk Ajar Melayu. Hal:xxxi). Dalam masalah ini penulis akan mengemukakan adat tradisi Ijab Kobul nikah kawin masyarakat Kecamatan Rumbai kota Pekanbaru. Bagi keluarga seorang gadis, adat perkawinan ini di maksud untuk mendapatkan keturunan yang akan melanjutkan keluarga dan melanjutkan warisan. Masyarakat Melayu pada umumnya mendambakan anak perempuan, bagi keluarga yang mempunyai anak laki-laki akan merasa bangga akan dapat mengganti orang tuanya di hari kelak dan menerima warisan keturunan dan memimpin kemenakannya setiap urusan teruutama urusan adat nikah kawin.

Seperti yang telah diuraikan hubungan antara anak laki-laki dan perempuan merupakan penyambung keturunan bagi keluarganya untuk mengatur hubungan itu, aturan perkawinan diadakan agar tidak terjadi hubungan tanpa aturan dan norma-norma yang menyebabkan terbengkalainya urusan anak-anak keturunan.

Aturan-aturan atau norma dalam tradisi nikah kawin atau perkawinan diadakan, guna membersihkan keturunan dari fitnah, sebab dengan melakukan pernikahan akan terhindar dari maksiat.

Orang yang mendapat anak tetapi tidak jelas asal usul bapaknya di anggap mencemarkan nama baik keluarga dan keturunan keluarga tersebut. Oleh karena itu, dalam mencari menantu selalu di perhatikan keturunan bakal menantu tersebut. Karena orang tidak ingin keturunannya tercemar di kemudian hari, sebab anak yang lahir di luar perkawinan syah akan dikatakan anak haram atau anak jadah dan amat hina di dalam pandangan masyarakat. Orang yang merusak nama keluarga dalam masalah perkawinan ini akan mendapatkan sanksi sosial, ia akan di kucilkan di masyarakat, mereka tidak mendapatkan apa-apa kecuali malu 
selama-lamanya. Biasnya ia akan pergi meninggalkan kampung halamannya dan tidak akan pulang, termasuk keluarga yang ditinggal pun mearasa malu.

Di samping faktor adat-istiadat, faktor agama pun menjadi sebab yang mendorong orang untuk menikah dan karena itu tujuan perkawinan adalah untuk memenuhi seruan agama yakni agama Islam. Menika di anggap mengikuti sunnah nabi, merupakan perbuatan yang terpuji dalam agama jika syarat-syarat terpenuhi. Menurut ajaran agama Islam ada masanya seseorang wajib kawin yakni untuk orang-orang yang tidak dapat menghindari fitnah, yakni hubungan tanpa nikah atau perkawinan yang mengatur hubungan tersebut.

Dalam setiap upacara perkawinan yang sebelumnya diawali dengan cara pendeatan-pendekatan bagi kedua bela pihak keluarga. Baik pihak laki-laki maupun pihak keluarga perempuan. Adapun waktu pendekatan tersebut biasanya di lakukan pada malam hari, sesudah shalat Isya. Wakil anggota keluarga laki-laki yang datang pada keluarga perempuan terdiri atas beberapa orang yang di anggap dapat memperlancar urusan peminangan tersebut dan di antara mereka ada seseorang yang di tuakan sebagai ketua rombongan,yang menjadi juru bicara di rumah keluarga perempuan. waktu yang diterapkan sebelum masa pertunangan kepada masa perkawinan tergantung kepada kesepakatan antara kedua belah pihak, Secara umum, proses pelaksanaan upacara adat perkawinan Melayu Kecamatan Rumbai /Rumbai kota Pekanbaru Riau. Yang meliputi 3 tahapan, yaitu persiapan, pelaksanaan, dan penutupan.

Adat nikah kawin masyarakat Kecamatan Rumbai Kota Pekanbaru Provinsi Riau tidak terlepas dari pengaruh suku bangsa pendatang terutama pengaruh dari sisi keagamaan. Contohmya ritual-ritual dalan bentuk tepuk tepung tawar,konon ini tradisi agama Hindu, namun karena ini merupakan suatu yang tidak bertentangan,sebab saat proses tepung tawar intinya mengucapkan selamat saja barulah di tutp dengan doa secara Islam (OK.Nuzami Jamil. Adat Perkawinan Melayu Riau. Hal:1).

Nikah kawin terjadi tentu saja berawal dari sentuhan, pandang memandang. Dalam hal ini besar kemungkinan bermula dari sentuhan pandangan dari seorang laki-laki dengan perempuan. tapi juga bisa terjadi dari pandangan ibu bapak atau pun kawan kerabat yang berminat untuk menikah kannya.(Hamidy, 2014. Jagad Melayu Dalam Lintasan Budaya di Riau. Hal:31).

Di dalam melaksanakan suatu upacara perkawinan akan selalu mengacu kepada tata upacara adat yang sudah di atur dan berlaku baik di tatanan istana maupun di khalayak ramai yang disesuaikan pula dengan alur dan patutnya.Secara umum bagian dari tata upacara adat perkawinan tersebut adalah sebagaimana di susun 
sedemikian rupa. Sehingga di dalam mencari jodoh anak haruslah melalui para orang tua dan si anak cukup menyampaikan keinginan kepada kedua orang tua..Jika seorang anak tertarik akan seorang gadis maka ia akan menyampaikannya kepada kedua orang tuanya.(Encik Zulkifli.2004.Adat Perkawinan dan PakaianTradisional Masyarakat Melayu kota Pekanbaru.Hal:3).

\section{Metode Penelitian}

Metodologi penelitian ini adalah pendekatan kualitatif dengan jenis penelitian study kasus. Penelitian kualitatif adalah suatu proses penelitian dan pemahaman yang berdasarkan pada metodologi yang yang menyelidiki suatu fenomena sosial dan masalah manusia dalam berintereaksi. Pada penelitian ini penulis membuat suatu gambaran konteks, kata-kata laporan yang terinci dari pandangan responden dan melakukan study pada stuatuasi yang alami (Creswell, 2017:15).

Bogdan dan Taylor (Moloong, 2017:3) mengemukakan bahwa metodologi kualitatif merupakan prosedur penelitian yang menghasilkan data deskriftip berupa kata-kata maupun lisan dari orang-orang prilaku yang diamati. Peneltian kualitatif dilakukan pada kondisi alamiah dan bersifat pemetaan.

Kemajemukkan masyarakat dan budaya Melayu Riau secara jelas dapat di lihat dari berbagai kelompok masyarakat. Dengan adanya keberagaman budaya,kesenian yang tradisonal, ini dapat kita lihat ketika mereka melaksanakan ritual berupa upacara-upacara adat dan tradisi termasuk upacara adat perkawinan. Upacara adat perkawinan masyarakat Melayu Riau sangat bergantung kepada adat atau susur galur peraturan dalampelaksanaannya. Susur galur peraturan tersebut melibatkan tata cara komunikasi yang yang di gunakan ketika proses-proses adat perkawinan berlangsung, hal sesuai dengan petuah "adat kerja baik berhimbauan kerja buruk berhambauan, kerja buruk jauh samasekali atau berbuat baik berpadapada, berbuat buruk jangan samasekali" artinya bila berbuat baik hendaknya di beri tahu kepada orang lain, bila berbuat buruk jangan sama sekali, jauhilah.(Nizami Jamil, 2008)

\section{Hasil dan Pembahasan}

Instrumen dalam penelitian ini adalah bentuk dokumentasi, di rekam melalui wawancara dan di catat dilapangan berdasarkan prosedur dan dikumpulkan serta dianalisa mana saja di anggap perlu dan penting dengan mengetahui keadaan di masyarakat (tokoh budaya, tokoh adat, penelitian 
inidilaksanakan selama 1 bulan tahun 2017. Tempat penelitian ini dilkaukan di Kecamatan Rumbai Kota Pekanbaru Riau.

Menurut Al-azhar (wawancara), 2017, tradisi ijab kobul di Kota Pekanbaru sungguh banyak ragamnya, bergantung kepada komnitas di mana ia berada dan di sesuaikan pada tempat-tinggalnya. Sebab dalamtradisi ijab kobul tersebut tidak ada yang mengatur dengan mengharuskan sesuatu, tambahnya lagi semakin banyak ragam budaya kita, akan semakin kaya khazanah budaya untuk bangsa ini.

Menurut Nasir (wawancara), 20 Juni 2017, iaadalah toko adat Lembaga Melayu Riau. Mengatakan bahwa keragaman budaya itu berarti menunjukkan bahwa tradisi nikah kawin di Riau cukup hidup, dengan bukti setiap kegiatan masyarakat khususnya dalam adat nikah kawin berubah-berubah dan menarik.

Di dalam buku Tata Cara Berbusana Melayu, 2013 dalam bentuk ungkapan adat Mealayu "adat memakai pada yang sesuai, adat duduk pada yang elok,adat berdiri tahukan diri”. Ungkapan ini mengandung makna yang sangat dalam, intinya dalam ungkapan ini memberikan petunjuk, bahwa setiap orang di tunntut untuk meletakkan sesuatu pada tempatnya, berperilaku menurut alur, dan tempatnya. Di dalam hal ini sesuai yang di kaji yaitu keberagaman yang menyesuaikan pada tempat dan di mana melakukannya, seperti dalam acara ijab kabul dalam suatu pernikahan. Sesuai yang memakai, sesuai dengan kepatutan.

Nilai tradisi mengandung arti sangat penting sanagat berguna bagi kepentingan manusia. Menurut U.U.Hamidy nilai pada dasarnya merupakan sesuatu yang abstrak dan sulit dikemukakan secara nampak oleh mata manusia, sebab nila lebih cendrung kepada sesuatu yang dapat dirumuskan bukan sesutu yang dapat ditunjukkan. Agar nilai dapat dilihat setelah mempergunakan panca indra, namun nilai yang di maksud dalam kajian ini adalah nilai tradisi dalam nikah kawin dimasyarakat Kecamatan Rumbai Kota Pekanbaru Provinsi Riau.di dalambuku O.K.Nuzami amil,2008 menjelaskan tentang adat nikah kawin masyarakat Riau sebagai berkut::

Persiapan. Pada tahap persiapan ini, masing-masing kedua keluarga pengantin di bantu oleh sanak kerabat dan tetangga jiran menyiapkan segala keperluan untuk proses adat perkawinan yang akan di lakukan. Mulai dari perlengkapan hingga kebutuhan lainnya.

Pertama Pelaksanaan. Pelaksanaan upacara adat perkawinan orang Melayu di Riau. Di gelar dalam beberapa tahap, yaitu merisik, meminang, antar belanja, menggantung, ijab qabul tepung tawar, berinai, berandam, khatam kaji, upacara langsung, berarak, membuka pintu, bersanding, makan bersuap, makan hadap- 
hadapan, menyembah mertua, mandi kumbo taman, makan nasi damai, dan upacara menyembah. Berikut adalah penjelasan dan pelaksanaan selengkapnya.

Keua Merisik Merisik adalah proses mengenali perempuan yang akan dijadikan istri. Proses ini dilakukan secara bertahap oleh pihak keluarga laki-laki. Caranya dengan mengirim orangtua laki-laki atau utusan untuk mencari informasi tentang calon istri, menyangkut tingkah lakunya, asal-usulnya, kemampuannya mengurus rumah tangga nanti, perlakuannya terhadap orangtua, tetangga, dan masyarakat. Satu hal yang terpenting adalah menanyakan apakah anak perempuan tersebut sudah di tanggam atau di pinang oleh orang lain, atau sudah mengikat janji dengan orang lain. Jika sudah, kedatangan keluarga laki-laki hanya untuk menjalin persaudaraan. Merisik dilakukan setelah mendengar kabar dari calon suami bahwa ada gadis yang menjadi idaman hatinya. Merisik juga dilakukan oleh keluarga perempuan untuk menyelidiki calon pengantin laki-laki, tanpa memberitahu tujuan yang sebenarnya..

Ketiga Meminang Jika dalam proses merisik kedua keluarga bersepakat untuk menikahkan kedua anaknya, maka tahap selanjutnya adalah meminang. Pada tahap ini, pihak laki-laki mengirim utusan ke pihak perempuan untuk menyampaikan niat menikah pihak laki-laki. Utusan yang di kirim biasanya orang-orangtua pilihan yang bijak dan mengerti adat. Peminangan biasanya disampaikan dengan bahasa pantun dan pepatah petitih serta diawali dengan ritual tepak sirih Melayu.

Keempat Antar Belanja. Sembari menunggu hari pernikahan, pihak laki-laki melakukan tahap antar belanja, yakni mengirimkan barang-barang tertentu, seperti uang atau cincin ke pihak keluarga perempuan dengan tujuan membantu keluarga perempuan dalam menggelar upacara perkawinan dan sebagai ikatan janji bahwa kedua keluarga akan menikahkan anaknya. Pada sebagian orang Melayu Kecamatan Rumbai dan Rumbai Pesisir di Riau.tahap ini juga biasa di isi dengan ritual tukar cincin. Antar belanja umumnya disesuaikan dengan derajat dan kedudukan pihak laki-laki di mata sosial. Besarnya hantaran dimungkinkan dapat mengangkat derajat pihak laki-laki. Pada tahap ini, kedua belah pihak menyepakati waktu akad nikah dan upacara langsung atau (bersanding/resepsi) di pelaminan akan di laksanakan.

Kelima Menggantung Tahap ini di isi dengan menghias rumah (tengah rumah), pelaminan, tempat tidur, dan tempat bersanding kedua pengantin kelak di rumah pengantin perempuan. Kegiatan ini dilakukan oleh keluarga dan kerabat dibantu oleh tetangga dan orang tertentu. Pada tahap ini pula, orangtua mempelai perempuan akan melakukan ritual tepuk tepung tawar di setiap sudut tempattempat di atas. Ada perbedaan dalam pemasangan pelaminan, untuk raja 
pelaminannya tingkat 9 , bangsawan 7 , datuk-datuk 5, dan orang biasa 3 . Namun, hal ini sekarang sudah di ubah dengan hanya ditentukan oleh kemampuan pihak keluarga.

Pada hari yang telah ditentukan, calon mempelai pria di antar oleh rombongan keluarga perempuan menuju ke tempat kediaman calon pengantin wanita. Biasanya calon mempelai pria berpakaian pakaian adat melayu kurung pengantin layaknya Raja sehari dan memakai tanjak (semacam topi untuk mempelai pria). Kedatangan keluarga mempelai pria sambil membawa mahar atau mas kawin, tepak sirih adat, barang hantaran atau seserahan yang telah disepakati sebelumnya. Selain itu, juga menyertakan barang-barang pengiring lainnya seperti kue-kue dan buah-buahan. Prosesi berikutnya adalah pelaksanaan akad nikah.

Pelaksanaan akad nikah biasanya dilaksanakan pada malam hari. Setelah rombongan mempelai pria datang beserta rombongan mereka disambut langsung masuk kedalam rumah mempelai wanita. Acara dimulai dengan upacara tukarmenukar tepak sirih dan juga memakan sirih yang disediakan dari masing-masing mempelai. Kemudian dilanjut dengan acara ijab qobul oleh pengantin pria dan upacara tepuk tepung tawar oleh para tetua lelaki maupun perempuan dari pihak mempelai laki-laki dan perempuan. Setelah acara selesai, pengantin pria beserta rombongan kembali lagi ke rumah untuk mempersiapkan acara bersanding keesokan harinya.

Berikut prosesi Iab Kobul dalam acara nikah kawin masyarakat Kecamatan Rumbai Pekanbaru:

a. Minta Doa Restu Orang Tua /minta izin .Sebelum masuk ke tempat berlangsungnya ijab kobul, maka seorang anak sebelumnya meminta izin kepada orang tuanya di hadapan para tetamu orang ramai, apakah itu di rumah sendiri mupun di Kantor Urusan Agama(KUA). Agar keduanya saling merelakan semua yang sudah terjadi selamaserumah dengan orang tuadan saling mengikhlaskan semua pemberian orang tua terhadap anaknya. Di dalam meminta izn pula semoga mendapat ridoh Allah. Sebab ridho Allahb bergantung kepada ridho orng tuanya. Berikut kalimat yang diucapkan seorang perempuan kepada orang tuanya:

"wahai ayah, saya mohon maaf yang selama ini ayah telah membesarkan ananda dan begitu banyak kasih sayangmu kepada saya, memberikan pakaian selama ini,memberikan makan-minum kepada ananda, yang telah memberikan pendidikan sampai ananda tahu mana yang baik dan mana yang buruk, mana 
yang di suruh dan mana pula yang di larang, kini saatnya ananda akan berumah tangga",

Lalu ayahnya menjawab;

iya anakku, "ayah dan ibumu sudah memaafkan kamu, ayah juga demikian yang selama ini kita serumah barang kali banyak keinginanmu yang belum tercapai, termsuk cita-citamu, semua itu maafkan ayah dan ibumua".

Kemudian bapak KUA melatih orang tuanya untuk Kesiapan orang tua. Petugas (KUA) menanyakan kesiapan orang tua atau wali dari pengantin perempuan, biasanya KUA mencoba dan di dengankan oleh orang banyak terlebih dahulu sebelum ijab kabuldimulai, kalimat yang akan diucapkan oleh orang tua dalam ijab kobul harus sudah hapal dan lancar membacanya. Setelah di ulang dan hapal dan lancar,maka akan di mulai prosesi ijab kobul.

b. Ijab Kobul.

Ketika ijab kobul berlangsung,seorang mempelai perempuan tidak bersamaan duduk dengan mempelai lakai-laki. Biasanya perempuan itu berada di dalam kamar atau agak jauh dari tempat ijab kaobul. Sebab perempuan hanya mendengarkan saja dari jauh.

Adapun kalimat yang sudah lazim di lakukan seperti di bawah ini:

"wahai sipulan, kemudian di jawab oleh mempelai laki-laki, “ iya pak” “aku nikah kan engkau dengan anakku sipulan dengan maskawin sebentuk cincin dan seperangkat alat sholaat tunaiii" selanjutnya di jawab. laki-laki itu "aku terima nikah si pulan dengan maskawin sebentuk cincin emas dan seperangkat alat sholat tunaiii"

Lalu dua orang saksi akan menyebutkan syah dan disetujui KUA dan orang bayak, maka syahlah nikah kedua memplei tersebut serta.

c. Membaca Sighot Taklik

Sighot taklik di siniialah mempertegas sekaligus mengikrarkannya di hadapan orang ramai. Maknanya seorang suami berjanji akan mempergauli istrinya dengan baik sesuai syariat Islam. dan berjanji bertanggung jawab untuk memenuhi nafkah lahir dan batin. Kemudian seorang istri juga akan memberikan layanan yang baik sesuai tanggung jawab seorang istri 
Setelah prosesi ijab kobul selesai,makadilanjutkan dengan nasehat pengantin dari salah seorang ustadz atau tokoh masyarakat yang sudah dipersiapkan sebelumnya oleh pihak pengantin.

\section{d. Penyerahan Buku Nikah}

Setelah mendengarkan sighot taklik,maka kedua pengantin menandatangani buku nkah, setelah di tanda tangani KUA langsung menyerahkan buku tersebut ke masing-masing pengantin. Buku tersebut berbeda warna. Satu untuk suami dan satu lagi untuk istrinya.

e. Nasehat Pengantin

Nasehat pengantin ini biasanya di lakukan agar pengantin mendapat bekal,bekal untuk menjalankan rumah tangga, walaupun sudah mendapatkan nasehat dari Kantor Urusan Aagama (KUA) sebelum menikah, kalau sekarang nasehat setelah resmi menjadi suami istri oleh ustadz atau tokoh masyarakat dari keluarga atau sahabat keuarga lainnya.

\section{f. Sombah Sujud}

Dalam hal ini kedua pengantin bersujud sombah kepada kedua orang tua, baik orang tua laki-laki maupun orang tua perempun, yang di dahuluioleh suami bersujud kepada orang tua suamidi ikuti oleh istrinya dan begitu seterusnya kepada kedua orang tua istri dan yang patut di sekitarnya.

\section{g. Tepuk Tepung Tawar.}

Tepuk tepung tawar ini sebagai simbol kebahagiaan. Tepuk tepung tawar ini gunanya untuk masyarakat, jiran, tetangga yang belum sempat menepuk tepung tawar,agar masyarakat umum dan teman dapat menepuk tawari juga, sebab sebelumnya secara simbolis sudah dilakukan oleh keluarga dekat, baik keluarga dekat pihak pengantin lelaki maupun pengantin perempuan. tepuk tepung tawar ini biasanya ada hiburan yang di sebut berzanji, atau rebana..7.Pembacaan Doa.

\section{h. Pembacaan Doa}

Berdoa yang di maksud di sini ialah untuk kebaikan pengantin yang baru saja dinikahkan agar hidup berumah tangga tetap sehat menjadi rumah tangga sakinah mawaddah dan rahmah dari Allah Swt. Yang memimpindoa ini bolehseorang KUA atau juga di pimpin oleh ustadz lainnya yang telah di tunjuk oleh tuan rumah. 


\section{i. Makan Bersama}

Dengan makan bersama ini menunjukkan bahwa remilah kedua mempelai menjadi hidup baru. Makan bersaa ini tentu adalagi makan secara simbolis yaitu seorang istri menyuapkan nasi kepada suaminya,dan sumai juga menyuapkan kepadaistrinya. Artinya mereka berdua setia dan saling menghormati dan saling mencintai. Sehingga setelah makan dan berumah tangga tetap setia yang menjadi ukuran.

j. Sambutan Tuan Rumah Setelah makan bersama ada juga membuat acara resmi dengan memberikan sambutan sekaligus mempersilahkan para tamu undangan yang sudah tiba sebahagian di tempat pengantin yaitu pengantin perempuan, sebab sebahagian besar pesta perkawinan itu dilaksanakan di rumah perempuan atau di hotel. Menutut Ust. Yusuf. Kenapa pesta itu dilaksanakan ditempat perempuan,karena sesuai dengantujuannyaa ialah agar orang tahubahwa seseorang perempuan itu sudah menikah. Sebab makan bersama tadi itu ialah makan bersama dengan pengantin bersama para undangan pernikahan saja yang hadir untuk menyaksikan proses ijab kobul saja.

k. Bersanding.

Ketika tuan rumah memberikan sambutannya berarti pengantin sudah berada di pelaminan.

\section{Kesimpulan}

Berdasarkan pengamatan dan wawancara peneliti di lapangan khususnya di Kecamatan Rumbai kota Pekanbaru bahwa keberagaman adat dan tradisi dalamacara nikah kawin ternyata kaya dan menarik.itulahsebabnya adat nikahkawin terutama tradisi ijab kobul dalamnikah kawin selain yang sudah ditetapkan dari sisi agama Islamjuga terkontaminasi oleh budaya-budaya yang ada di daerah ini sebagai pendatang. Selain itu juga di pengaruhi oleh budaya asing.

Dengan penelitian ini penulis dapat menyimpulkan bahwa setiap manusia apa pun latar belakangnya pendidikannya akan melaksanakann adat tradisinya ketika nikah kawin. Bergantung kemampuannya masing-masing, bagi yang mampu maka maka ia akan melaksanakan adat perkawinannya dengan besar- 
besaran dengan mengundang orang bayak dan memenuhi adat istiadatnya,. Bagi masyarakat yang kehidupan ekonominya sedang atau sederhana,iakan tetap melakaukannya sesuai kemampuannya masing-masing. Dengan banyaknya keberagaman itu semakin kaya khazanah budaya danmenarik di mata masyarakat maupun di mata peneliti. 


\section{Daftar Pustaka}

Depdikbud, 2006. Upacara Tradisional pada Masyarakat Melayu Kampar

Balai Kajian Sejarah dan nilai Tradisional Tanjung Pinang

Kaflany HD. 1992. Islam Dan Aspek-Aspek Kemasyarakatan. Bumi Aksara.

Jakarta

Koentjaraningrat, 1990. Kebudayaan Metalitas dan Pembangunan

- Jakarta:Gramedia Pustaka Utama

Nizami Jamil. O.K, 2008. Adat Perkawinan Melayu Riau. Lembaga Adat

Melayu Riau Pekanbaru.

Tenas Effendy,Tunjuk Ajar Melayu. Dinas Kebudayaan dan Pariwisata Provinsi Riau.

Yulia wati. 2000. Senarai Upacara Adat Perkawinan Melayu Riau. Pekanbaru.

Dinas Kebudayaan,Kesenian dan Pariwisata Provinsi Riau. 2013. Tata Cara Berbusana Budaya Melayu. Pekanbaru.

Hamidy, 2014. Jagad Melayu Dalam Lintasan Budaya di Riau. UIR Press

Pekanbaru..

OK. Nuzami Jamil. Adat Perkawinan Melayu Riau. Hal:1.

Encik Zulkifli. 2004. Adat Perkawinan dan Pakaian Tradisional Masyarakat Melayu kota Pekanbaru.Hal:3. 
